\title{
Efficiency of functioning solar collectors in selected households
}

\author{
Alina Kowalczyk-Juśko ${ }^{1, *}$, Pawet Roczeń ${ }^{1}$ \\ ${ }^{1}$ University of Life Sciences in Lublin, Department of Environmental Engineering and Geodesy, Leszczyńskiego St. 7 , \\ 20-069, Poland
}

\begin{abstract}
The article presents the results of research on the efficiency of the solar collector system in south-eastern Poland. The basis of the article are the results of actual measurements recorded by the system measuring in 5 years (2014-2018). Three solar collectors with a total gross area of $6.3 \mathrm{~m}^{2}$ are used to heat utility water in a single-family house. The average annual heat production in this system was $1916 \mathrm{kWh}$. The system's work was characterized by high seasonal and daily variability, which is related to the Polish climate's specificity. Using the energy production data, the reduction of pollutant emissions achieved by changing the energy carrier was calculated: from electricity to heat from a renewable source, which is solar radiation. The installation of solar collectors allowed for satisfying part of the energy demand as well as reducing the emission of greenhouse gases and other pollutants into the atmosphere.
\end{abstract}

\section{Introduction}

The increase in the population's energy demand has contributed to the search for alternative sources of energy. One of the most commonly used renewable energy sources (RES) is solar radiation. The sun and its energy are the primary source of most renewable energy: wind energy (due to the movement of air masses at different temperatures), water (the circulation of water in nature depends on its evaporation) [1,2] and biomass [3], whose growth depends on the phenomenon of photosynthesis [4]. Solar energy is indicated as the most important source of energy for humanity in the long term, when the importance of other renewable energy sources decreases, i.e., in about 100-150 years [5]. Currently, solar radiation is used to generate electricity using photovoltaic panels [6] and thermo-solar power plants [7], heat on the scale of single-family buildings [8] and multi-family buildings [9], desalination water [10], drying of agricultural products [11], as well as in various hybrid combinations [12]. By appropriate construction and location of buildings in relation to the incident sun rays, their heat balance can be improved [13].

One of the more straightforward ways to use solar energy are solar collectors that convert solar radiation to heat [14]. In the latitude of Poland, such installations are mainly used for heating utility water. However, a sufficiently efficient collector system can complement the central heating of a building or swimming pool water [15].

The most common devices for converting solar energy into thermal energy are solar collectors of various types: flat, tube, liquid, vacuum $[16,17]$. The collector power is selected depending on the needs of a given household, farm, or enterprise.
The article aims to assess the effectiveness of the solar collector system used to heat utility water in a single-family house. Based on 5-years measurements, the variability of device operation was assessed, on a monthly and daily basis. The reduction of pollutant emissions to the atmosphere was also calculated, which was obtained by replacing the electric water heater with solar collectors.

\section{Materials and methods}

\subsection{Research object}

The object of research is a solar collector system used to heat utility water in a single-family residential building in Płonka, Lublin Voivodeship, Poland (N: 50 50'39; E: $\left.22^{\circ} 58^{\prime} 48^{\prime \prime}\right) .4$ adults inhabit the house. Before installing the collectors, the utility water was heated using an electric boiler. The solar water heating system was installed at the end of 2013. It consists of three flat, liquid solar collectors with a total gross area of $6.3 \mathrm{~m}^{2}$. They are located on the roof of the building, at an angle of $30^{\circ}$ to the horizontal, facing south. The installation's pump control unit is located in the basement of the building. The system includes a bunded buffer tank with a capacity of 3001 , in which heated water is collected. The system is equipped with a controller that controls: the flow of liquid in the collectors, recirculation of the fluid heated by the collectors, and prevents overheating of the system during intense sunlight. During low sun exposure, and in winter, the solar system is supported by a $14 \mathrm{~kW}$ central heating boiler, powered by black coal and wood.

\footnotetext{
Corresponding author: alina.jusko@up.lublin.pl
} 


\subsection{Assessment of the system's effectiveness}

The system for analyzing the efficiency of the collectors and their power is based on 4 sensors: 3 of them are located in different places of the solar installation, and 1 at the buffer tank. It is an automatic, built-in, internal measuring system, which gives the results of measurements of the amount of heat energy and power produced in daily, weekly, monthly and yearly summaries. Thanks to such a measuring system, it is possible to prepare solar collector performance reports. On their basis, the device calculates the appropriate performance values of the entire set throughout the year. Data, including the amount of energy production $[\mathrm{kWh}]$ and the average power [W] with which the system worked in the appropriate time, are saved in the device's memory. For proper assessment of solar systems operation it is necessary to measure the value of solar radiation in the solar collector plane. Pyranometers measuring this size are usually used in large photovoltaic systems because they are very expensive. That is why solutions for cheaper and sufficiently accurate sensors based on reference photocells are constantly being sought [18].

\subsection{Assessment of pollution reduction}

It was assumed that the amount of energy produced annually by collectors is equal to electricity saved during heating of usable water. The reduction of pollutant emissions was calculated using indicators for calculating emissions from electricity production [19], expressed in $\mathrm{kg} \cdot \mathrm{MWh}^{-1}$ :

- carbon dioxide $\left(\mathrm{CO}_{2}\right)-765$,

- sulfur oxides $\left(\mathrm{SO}_{\mathrm{x}} / \mathrm{SO}_{2}\right)-0.681$,

- nitrogen oxides $\left(\mathrm{NO}_{\mathrm{x}} / \mathrm{NO}_{2}\right)-0.631$,

- carbon monoxide $(\mathrm{CO})-0.275$,

- total dust -0.036 .

Additionally, for comparison, the reduction in $\mathrm{CO}_{2}$ emissions was calculated using the formula given by Lewandowski [20]:

$\mathrm{R}_{\mathrm{CO} 2}=\mathrm{A} \cdot 125\left[\mathrm{~kg} \mathrm{CO}_{2} \cdot \mathrm{a}^{-1}\right]$

where:

$\mathrm{R}_{\mathrm{CO} 2}$ - reduction of $\mathrm{CO}_{2}$ emissions

$\mathrm{A}-$ area of collectors $\left[\mathrm{m}^{2}\right]$

125 - factor reduction of $\mathrm{CO}_{2}$ emission $\left[\mathrm{kg} \mathrm{CO}_{2} \cdot \mathrm{m}^{-2} \cdot \mathrm{a}^{-1}\right]$

\section{Results}

\subsection{The efficiency of the collectors}

Based on the collected data from 2014-2018, we can trace the variability of energy production. The annual variability, illustrated in Figure 1, coincides with Poland's insolation index for eastern Poland [21]. The most energy in the climatic conditions of south-eastern Poland was obtained annually in July (average 336 $\mathrm{kWh}$ ), and the least in December (average $7 \mathrm{kWh}$ ). The average installation capacity, calculated on a monthly basis, was $451 \mathrm{~W}$ in July and $8 \mathrm{~W}$ in December, respectively.

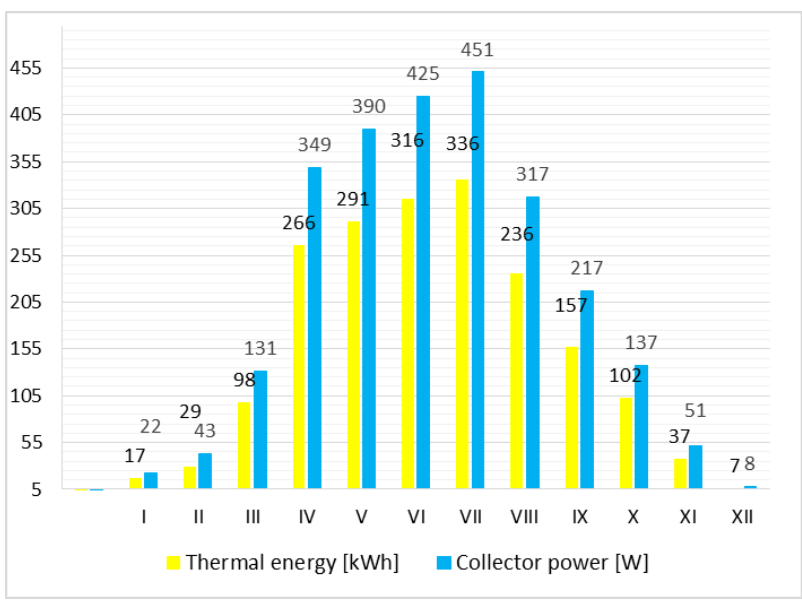

Fig. 1. Thermal energy production $[\mathrm{kWh}]$ and average collector power [W] in individual months of the year (2014-2018).

It should be noted that the average values do not reflect the actual variability of the installation's operation. A characteristic, negative feature of solar energy is its daily and seasonal variability and massive dependence on the weather. This variability can be traced by analyzing the results of measurements from four selected months of 2017 (Figure 2). Even in the month with the highest energy production rates (July), it can be said that there were days when the capacity of the installation was very low (July $12-3.20 \mathrm{kWh}$, July $31-$ $3.03 \mathrm{kWh}$ ). Cases of overheating of water in the tank have also been reported, which caused disturbances in the operation of the installation. On average insolated April 2017, there were days with full cloud cover, when energy production was zero (April 28) or close to zero (April $11-0.38 \mathrm{kWh}$ ). Only in December, there were no particularly large positive deviations in the value of energy production. Even considerable insolation that occurs this month does not have a significant impact on the operation of solar collectors, unlike photovoltaic panels, which in low-temperature conditions have higher efficiency [22]. Daily variability is the highest (daynight), therefore it is necessary to accumulate energy. Most often, it is stored in heated water. This solution is simple, but it has an impact on investment costs. In the examined object, the energy storage is an insulated 3001 water tank.

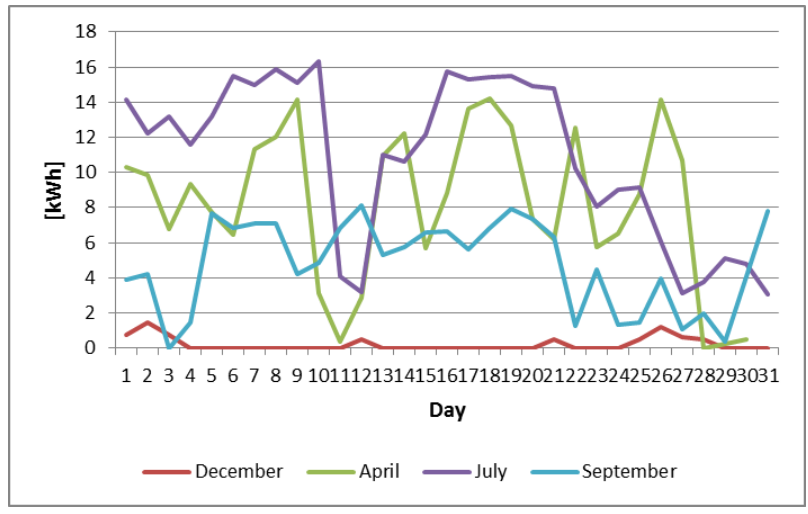

Fig. 2. Variation of daily heat production $[\mathrm{kWh}]$ in selected months of 2017. 
Annual energy production in the installation for 5 years ranged from 1751-2171 kWh and averaged $1916 \mathrm{kWh}$ (Figure 3). The unit efficiency of collectors amounted to $256.5 \mathrm{kWh} \cdot 1 \mathrm{~m}^{-2}$ gross collector area.

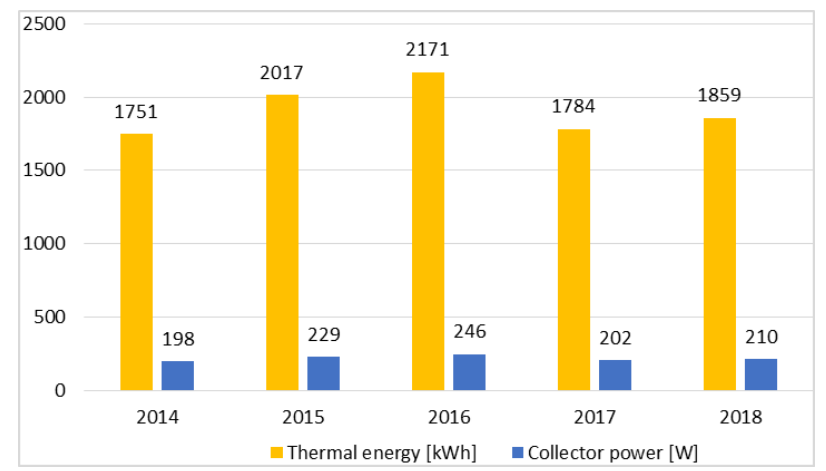

Fig. 3. Annual heat production $[\mathrm{kWh}]$ and average power $[\mathrm{W}]$ of the installation tested over 5 years of use.

Table 1. Reduction of air pollution emissions in individual years $[\mathrm{kg}]$

\begin{tabular}{|c|c|c|c|c|c|c|c|}
\hline \multirow{2}{*}{ Contamination } & \multirow{2}{*}{ Formula } & \multicolumn{5}{|c|}{ Year } & \multirow{2}{*}{ Average } \\
\cline { 3 - 7 } & & $\mathbf{2 0 1 4}$ & $\mathbf{2 0 1 5}$ & $\mathbf{2 0 1 6}$ & $\mathbf{2 0 1 7}$ & $\mathbf{2 0 1 8}$ & \\
\hline Carbon dioxide & $\mathrm{CO}_{2}$ & 1339.52 & 1543.01 & 1660.82 & 1364.76 & 1422.14 & 1466.05 \\
\hline Sulfur oxides & $\mathrm{SO}_{\mathrm{x}} / \mathrm{SO}_{2}$ & 1.1924 & 1.3736 & 1.4785 & 1.2149 & 1.2660 & 1.3051 \\
\hline Nitrogen oxides & $\mathrm{NO}_{\mathrm{x}} / \mathrm{NO}_{2}$ & 1.1049 & 1.2727 & 1.3699 & 1.1257 & 1.1730 & 1.2092 \\
\hline Carbon monoxide & $\mathrm{CO}$ & 0.4815 & 0.5547 & 0.5970 & 0.4906 & 0.5112 & 0.5270 \\
\hline Total dust & - & 0.0630 & 0.0726 & 0.0782 & 0.0642 & 0.0669 & 0.0690 \\
\hline
\end{tabular}

The calculation of the carbon dioxide reduction using the methodology given by Lewandowski [20] is presented below:

$$
\mathrm{R}_{\mathrm{CO} 2}=(3 \cdot 2.1) \cdot 125=6.3 \cdot 125=787.5 \mathrm{~kg} \mathrm{CO}_{2} \cdot \mathrm{a}^{-1}
$$

According to this calculation, which is based on the surface of the collectors and not their actual efficiency, the estimated reduction of carbon dioxide emissions is almost twice as low. This demonstrates the estimated nature of the calculation of the emission of pollutants and the need to provide the methodology on the basis of which these values are calculated.

\section{Conclusions}

From 2014 a solar collector system has been used in a single-family house located in the south-eastern part of Poland. It consists of 3 collectors with a gross area of 6.3 $\mathrm{m} 2$ and is used for usable water heating. Due to the Polish climate's specific nature, the installation is most effective in the period from March to October, which significantly reduces the cost of water heating. The coldest month in which collectors produced the least heat was December $(7 \mathrm{kWh})$, while in the warmest month of July, the installation was the most efficient and produced the most energy (336 kWh). The average annual energy production in the examined facility was $1916 \mathrm{kWh}$.

Analysis of long-term measurement reports from the solar system under study revealed cases of overheating (exceeding the set permissible temperature level) of water in the tank. This means that on days with the best sunshine, not all available solar energy was converted into heat. This had an obvious impact on the reported year-round amount of heat energy produced.

\subsection{Reduction of emissions of substances released into the air}

Due to the installation of solar collectors for water heating, the household's energy demand has decreased. The work of collectors practically does not cause any emissions to the environment. Thus, it can be considered that the amount of energy and the resulting emission of pollutants is eliminated when collectors produce energy. Based on this assumption, it was calculated that due to the functioning of the collector system, the average annual intake of the following amounts of air pollution was reduced (Table 1):

- $1466.05 \mathrm{~kg} \mathrm{CO}_{2}$,

- $1.3 \mathrm{~kg} \mathrm{SO}$,

$-1.21 \mathrm{~kg} \mathrm{NO}_{\mathrm{x}}$,

- $0.53 \mathrm{~kg} \mathrm{CO}$,

- $0.069 \mathrm{~kg}$ of dust.
An efficiently operating heating system based on a renewable energy source, which is a solar installation, has reduced the consumption of energy, which has so far been heated. This resulted in an ecological effect in reducing emissions of pollutants into the atmosphere, including greenhouse gases.

\section{Acknowledgements}

Publication is funded by the Polish National Agency for Academic Exchange under the International Academic Partnerships Programme from the project „Organization of the 9th International Scientific and Technical Conference entitled Environmental Engineering, Photogrammetry, Geoinformatics - Modern Technologies and Development Perspectives".

\section{References}

1. A. Kowalczyk-Juśko, A. Mazur, A. Grzywna, A. Listosz, R. Rybicki, A. Pytka, O. Dorozhynskyy, K. Jóźwiakowski, M. Gizińska-Górna, Journal of Water and Land Development 35, 113-119 (2017) doi: 10.1515/jwld-2017-0074

2. A. Mazur, A. Grzywna, A. Kowalczyk-Juśko, J. Cybulski, Journal of Ecological Engineering 17 (5), 254-260 (2016) doi: 10.12911/22998993/66256

3. W. Czekała, S. Bartnikowska, J. Dach, D. Janczak, A. Smurzyńska, K. Kozłowski, A. Bugała, A. Lewicki, M. Cieślik, D. Typańska, J. Mazurkiewicz, Energy 159, 1118-22 (2018) doi: 10.1016/j.energy.2018.06.090 
4. D.H. Greer, Environ. Exp. Bot. 138, 10-20 (2017) doi: 10.1016/j.envexpbot.2017.03.001.

5. R. Galvin, Energy Res. Soc. Sci. 65, 101455 (2020) doi: 10.1016/j.erss.2020.101455.

6. M.M. Fouad, L.A. Shihata, E.S.I. Morgan, Renew. Sustain. Energy Rev. 80, 1499511 (2017) doi: 10.1016/j.rser.2017.05.141.

7. O. Behar, Renew. Sustain. Energy Rev. 92, 608-27 (2018) doi: 10.1016/j.rser.2018.04.102.

8. E. Jahani, K. Cetin, I.H. Cho, Build. Environ. 172, 106667 (2020). doi: 10.1016/j.buildenv.2020.106667.

9. C. Reddick, M. Sorin, J.C. Bonhivers, D. Laperle, Energy Build. 211, 109803 (2020). doi: 10.1016/j.enbuild.2020.109803.

10. J. Han, X. Ji, H. Xu, Y. Heng, C. Wang, J. Deng, Renew. Energy 154, 201-8 (2020) doi: 10.1016/j.renene.2020.02.105.

11. A.B. Lingayat, V.P. Chandramohan, V.R.K. Raju, V. Meda, Appl. Energy 258, 114005 (2020) doi: 10.1016/j.apenergy.2019.114005.

12. K. Li, C. Liu, S. Jiang, Y. Chen, J. Clean Prod. 250, 119481 (2020) doi: 10.1016/j.jclepro.2019.119481.

13. D. Mazzeo, K.J. Kontoleon, Sustain. Cities Soc. 60, 102111 (2020) doi: 10.1016/j.scs.2020.102111.

14. L. Evangelisti, R. De Lieto Vollaro, F. Asdrubali, Renew. Sustain. Energy Rev. 114, 109318 (2019) doi: 10.1016/j.rser.2019.109318.

15. B. Igliński, M. Cichosz, W. Kujawski, M. PlaskaczDziuba, R. Buczkowski, Renew. Sustain. Energy Rev. 58, 862-70 (2016) doi: 10.1016/j.rser.2015.12.244.

16. E. Azad, Renew. Sustain. Energy Rev. 16, 2833-8 (2012) doi: 10.1016/j.rser.2012.02.001.

17. A. Fudholi, K. Sopian, Renew. Sustain. Energy Rev. 102, 333-45 (2019). doi: 10.1016/j.rser.2018.12.032.

18. T. Rodziewicz, J. Teneta, A. Zaremba, M. Wacławek, Ecol. Chem. Engin. 23 (4), 583-591 (2016) doi: 10.1515/eces-2016-0041

19. Emission factors of $\mathrm{CO}_{2}, \mathrm{SO}_{2}, \mathrm{NO}_{\mathrm{x}}, \mathrm{CO}$ and total dust for electricity. (KOBiZE, Warszwa, 2019).

20.W. M. Lewandowski, Pro-ecological renewable energy sources (WNT, Warszawa, 2007)

21. T. Rodziewicz, J. Teneta, A. Zaremba, M. Wacławek, Ecol. Chem. Engin. 20 (1), 177-198 (2013) doi: 10.2478/eces-2013-0014.

22. M. Jaszczur, J. Teneta, Q. Hassan, E. Majewska, R. Hanusz, Heat Transfer Engin. (2019) doi: 10.1080/01457632.2019.1699306 